\title{
HALAL-FRIENDLY TOURISM BUSINESS PROCESS: TOURISM OPERATORS IN INDONESIA
}

\author{
Junaidi JUNAIDI* \\ Faculty of Humanities, Universitas Lancang Kuning, Jl. Yos Sudarso KM. 8, \\ Umban Sari, Rumbai, Pekanbaru, Riau, Indonesia, e-mail: junaidi@unilak.ac.id

\section{Afred SUCI} \\ Department of Business and Administration, National University of Science \\ and Technology Taiwan, No. 43, Keelung Rd., Sec. 4, Da'an Dist., Taipei 10607, \\ Taiwan, e-mail:d10708806@mail.ntust.edu.tw
}

\section{Satria Tri NANDA}

Faculty of Economic, Universitas Lancang Kuning, Jl. Yos Sudarso KM. 8, Umban Sari, Rumbai, Pekanbaru, Riau, Indonesia, e-mail: satriatrinanda@unilak.ac.id

\section{Bagio KADARYANTO}

Faculty of Law, Universitas Lancang Kuning, Jl. Yos Sudarso KM. 8, Umban Sari. Rumbai, Pekanbaru, Riau, Indonesia, e-mail: bagio.kadaryanto@gmail.com

Citation: Junaidi, J., Suci, A., Nanda, S.T., \& Kadaryanto, B. (2019). HALAL-FRIENDLY TOURISM BUSINESS PROCESS: TOURISM OPERATORS IN INDONESIA. GeoJournal of Tourism and Geosites, 27(4), 1148-1157. https://doi.org/10.30892/gtg.27403-422

\begin{abstract}
The aim of the research is to recognize the tourism industry in halal tourism concept, business process, and dilemma. Authors determine the strategies to resolve the dilemmas based on the situation of the tourism business operators. The study engaged with the situations of halal business operators. The data were collected through in-depth interview with four tourism operators in Indonesia who won the best halal category award by The World Halal Travel Award in Dubai. The results of this study found that all participants choose to be Muslim-friendly business instead of pure sharia business. This business process transformation helps to expand their market segment to Muslim tourists at tolerable cost. The existing dilemmas by tourism industry are no formal standard of halal criteria, high-cost business transactions, lack of sharia-competent human resources, and lack of tourism promotions. Niche market-based premium price could be a solution to compensate the additional high cost and potential lost that may occur in case of transforming conventional business into halal business platform.
\end{abstract}

Key words: Halal Tourism, Best Practices, Constraints, Strategy

\footnotetext{
* Corresponding author
} 


\section{INTRODUCTION}

Nowadays, halal is the lifestyle of global consumers (Boediman, 2017). Halal is not only for food products but also non-food products such as cosmetics, pharmaceuticals, leather crafts, and fragrances. It is included services such as banking, entertainment, tourism and logistics (Rahim et al., 2013). According to Harahsheh (2019), tourism is widely influenced by religious beliefs which generate the appearance of halal tourism.

The rapid growth of the halal tourism industry is determined by awareness of Muslims on halal tourism as well as the rise of the Muslim population (Rahim et al., 2013). CresentRating.com finds that Muslim tourists contribute $12.3 \%$ to the world's total tourist expenses (Osman et al., 2015). However, there are limitations for halal-based tourism operators. First, there is no formal standard of halal in the management of sharia-compliant tourism business. Although Indonesia is the most populous Muslim country in the world, some halal tourism operators refused the Minister of Tourism and Creative Economy Regulation Number 2 of 2014 on the Guidelines for the Implementation of Sharia Hotel Business. It is related to the revocation of the regulation. This refusal shows that there is different perception in sharia tourism among tourism operators. In addition, the fatwa of DSN-MUI (National Sharia Board of The Indonesian Council of Ulama) Number 108/DSN-MUI/X/2016 on Guidelines for Implementing Sharia-Compliant Tourism (DSN-MUI, 2016) does not specifically require this matter technically because it merely contains normative rules by sharia tourism providers.

This ironic phenomenon is not only happened in Indonesia, but it is also happened in other Muslim countries. Egypt and some Middle East countries are facing lack of references and standards about the implementation of sharia-compliant tourism. The implementation of sharia principles in Egypt is even often contrary to state regulations in the completeness of international hotel facilities for the 4 and 5 star hotel category (Saad et al., 2014). It is the reason of international hotels to refuse the implementation of sharia in hotels (Razalli et al., 2012). Furthermore, the halal tourism's point of view criteria in each country also vary. Zamani and Musa (2012) state that even in Muslim countries, their opinions on the sharia implementation are heterogeneous due to different interpretation of Islam and local culture, the degree of liberalism and state intervention. In this case, Egypt, Morocco, the United Arab Emirates and Malaysia are more flexible in implementing sharia in their tourism industry, while Iran, Saudi Arabia and Brunei Darussalam are considered more rigid (Kovjanic, 2014). There are a lot of studies about the challenges and strategies of halal tourism industry. However, these studies did not involve tourism business operators who won the world's best prize in the implementation of sharia business. Their best practice is highly required to comprehend tourism business nowadays. The majority of stakeholders are already familiar with conventional tourism business practice. Thus, the aim of the research is to recognize the tourism industry in halal tourism concept, business process, and dilemma based on the best practices of the winning halal tourism operators. Authors determine the strategies to resolve the dilemmas based on the situation of the tourism business operators.

\section{LITERATURE REVIEW}

Tourism theory is important to comprehend the tourism issues (Stergiou \& Airey, 2018). Tourism will never be an autonomous field of science, because practically it will involve many disciplines such as socio-cultural (Wyllie, 2011). The term of "tourism" is firstly developed from the habits of wealthy people in England who sent their young men to study throughout Europe (Leiper, 1979). Currently, the term has involved almost all aspects of human life (Ma \& Law, 2009). The notion of tourism is a popular term in outside of the zone of these issues for a period of time and outside the regular activity to 
learn and make an experience with new places to relaxation (Chadwick, 1987; Firdaus et al., 2019). Although Graf \& Ossig (2002) claim that travel does not correlate with tourist's motivation, but other studies reveal that the recognition of socio-cultural of the travel can be a motivation for tourists e.g. Rinschede, 1992 (Wyllie, 2011). Culturally, the tourist was influenced by the other people to make a desirable and worthy travel. Therefore, tourism marketers must be able to recognize tourist's intention. Understanding consumers' intention is the key to success in the tourism industry (Goeldner \& Ritchie, 2009). Moreover, tourism is a global phenomenon with various different types, environments, cultures, and tourist types (Firdaus, 2018; Goeldner \& Ritchie, 2009). Some of them even lead to a very specific Niche Tourism Market (special interest) targeting to a particular segment. One of the most dynamic is halal tourism. The concept of religious travel is identified by religious reasons (Rinschede, 1992). Religious travel might be the oldest form of tourism (Sigaux, 1996; Vukonic, 1996). Dogan (2011) proposes different concepts that Islamic tourism is activities by Muslims in tourist destinations for relaxation and entertainment purposes. It is presented by hospitality companies in Islamic principles.

These principles include the implementation of halal concepts in travel agency or known as halal or travel tourism. Battour et al. (2010) explains that sharia travel refers to a set of religious values and rules by human life. It is the interaction of human with all human beings in the world. The form of the tourism can be hijj. It is a trip to Mecca and Medina. It can be zejara that refers to Muslim holy places. It can be rihla that refers to travel for other reasons such as education, commerce and etc. Tourism in Islam consists of five purposes: (a) to worship, such as hajj and umrah, (b) to gain knowledge and experience, (c) to seek scientific truth in Al qur'an, (d) to talk to the man elsewhere, (e) to express gratitude and awe of Allah's creation while enjoying the beauty of place (Jaelani, 2017).

Islam strongly encourage to travel as written in $\mathrm{Al}$ qur'an and hadith (Musa et al., 2016). Therefore, there are provisions about Islamic tourism such as mustabahah. It is a travel to do dakwah (talk) and to contemplate the signs of nature's greatness. Mubah (acceptable) is a travel for enjoyment and pleasure but without making any immorality manner. Makruh is avoided travel although it is not immoral (Alim et al., 2015). Thus, the travel is for merely entertainment value. It is not for religious purpose or haram (prohibited). This kind of travel is for immoral entertainment to disobey the rights of God and to participate in religious rituals of other religions.

The concept of halal in the context of tourism is evidence of Islamic in every aspect of a Muslim since Islam is a comprehensive religion (Samori et al., 2014). Islam has a holistic and comprehensive concept as the fundamental beliefs of Muslims. It provides solutions to problems and needs of Muslims through the implementation of various values (Battour et al., 2010). Halal terminology has a range of implementations such as human relations, dress and behavior ethics, social and business transactions, trades, services and investments and other aspects (Samori et al., 2014). It is included the desires to travel in Islam regulation. According to Henderson (2010), halal in Arabic terminology refers to "acceptable" or "allowed". This concept is not only for food, but it is also for cosmetics, vaccines and tourism. In addition, halal can be categorized as legal food and things in Islam (Samori et al., 2014), because the concept of halal refers to the ways to produce goods and services in Islamic ways (Bohari et al., 2013).

The emphasis of halal tourism is on the proper movement of an element of spiritual travel in service to God. Sharia determines the acceptable (halal) and unacceptable (haram) in everyday life and during the travel (Kovjanic, 2014). In Islam, human can not act arbitrarily in the world. Human must live and interact in the world through the sharia way. Human must realize that their action will be counted (Battour et al., 2010). Thus, Islamic terminology for this term is hisab. 
Tourism industry progressively starts to abandon the concept of mass marketing to be more segmented by targeting more specific consumer groups (El-Gohary, 2016). The development of a knowledge-based community allows tourists to have a high awareness and knowledge of a particular issue (Goeldner \& Ritchie, 2009). One of the main keys is the people awareness. They have better understanding of religious values in their life such as tourism activities. They are increasingly more wealth (economically), smarter (as more and more sources of information are available), and more religious (Yuswohady, 2015).

Nowadays, Muslim consumers do not only look for functional and emotional value of a product or service but it also focus on spiritual values of products or services. In the context of Muslim consumers, the main principal in the spiritual value is about the product or service to fulfill the daily needs in the Islamic's rules (Yuswohady, 2015). Moreover, religion is one of the highly influences factors in person's attitude, value and behavior and a social community (El-Gohary, 2016). Thus, religion has been one of the reasons to do travelling (Wall \& Mathieson, 2006).

\section{METHODS}

This research uses exploratory study to find out the best practice and assess of the most ideal strategy of halal-tourism operation. Data, mainly findings from observations and in-depth interviews, were discussed in qualitative approach (Creswell, 2014). Semistructured interview was designed to open more possibility in generating information. The interview took approximately one hour. All conversations were recorded, transcribed and finally analyzed using the content analysis which is a technique for replicable. It is valid inferences from texts in order to discover the text (Sekaran \& Bougie, 2013). The interview is interpreted and analyzed by triangulation method to check and recheck with other sources such as books, research results, and official reports to validate the informations (Sugiyono, 2015). The participants are successful halal tourism operators in Indonesia. Participants have the award from World Halal Travel Award in Dubai - as the best of halal tourism assessment categories such as: (1) Sofyan Hotel in Jakarta was awarded as The World's Best Family Friendly Hotel in 2015; (2) The Radhana Hotel in Kuta - Bali won the World Best Family Friendly Hotel in 2016; 3) Novotel Lombok Resort and Villas in Lombok - West Nusa Tenggara won the World Best Halal Beach Resort in 2016; (4) Sembalun Village Region, Lombok in West Nusa Tenggara achieved the World Best Halal Honeymoon Destination in 2016. The participants are contacted by email to set the meeting on site.

\section{RESULTS DISCUSSIONS}

\section{Obligations and Restriction in Halal Tourism}

For Muslim tourists, the need to obey the requirements of tourism services is very different from other types of international tourism. Requirements of Muslim tourists often can not be fulfilled by the international tourism industry in the conventional concept (Widayati \& Setiyorini, 2014). The most important rule in the concept of halal tourism is based on the the values of the needs of Muslim tourists. They are the comfort and peacefulness in a travel without breaking Islamic principles (Alim et al., 2015). Then, it is natural that Muslim tourists insist certain requirements. It must not be ignored by tourism operators (Battour et al., 2010). There are sharia restrictions on tourism components, which are commonly found in conventional tourism practices, such as: alcohol, night entertainments, the mix of unauthorized women and men, etc.

\section{Best Practice of World Halal Tourism Award Winners}

\section{Product Aspects}

This study produced participants' interviews about the best practices by the award winners of halal tourism. They attempt the fundamental aspects of the formal standard of 
halal criteria for Muslim tourists such as the provision of halal food certified by the Indonesian Council of Ulama. It is also discussed shalat facilities in quantity and quality. Halal certification is not only for the tourism operators, but it is also about suppliers of the tourism operators. The most important product or service in the implementation of sharia tourism is the provision of halal food and beverages (COMCEC, 2016).

Table 1. Obligation and Restriction in Halal Tourism Business Process (Data Source: Data Processing Results, 2018)

\begin{tabular}{|c|c|c|c|}
\hline \multicolumn{2}{|r|}{ Obligation } & \multicolumn{2}{|c|}{ Restriction } \\
\hline Items & Sources $^{*}$ & Items & Sources $^{*}$ \\
\hline 1. Hygiene & $\begin{array}{l}\text { Idris and Wahab, 2015; } \\
\text { Qaddhat et al., 2016; } \\
\text { El-Gohary, 2016 }\end{array}$ & 1. Gambling & $\begin{array}{l}\text { Battour et al., 2010; } \\
\text { Idris and Wahab, 2015; } \\
\text { El-Gohary, 2016 }\end{array}$ \\
\hline $\begin{array}{l}\text { 2. Ethics of } \\
\text { dressing }\end{array}$ & $\begin{array}{l}\text { Idris and Wahab, 2015; } \\
\text { Qaddhat et al., 2016; } \\
\text { El-Gohary, 2016 }\end{array}$ & $\begin{array}{l}\text { 2. Entertainments } \\
\text { that against the } \\
\text { principles of sharia }\end{array}$ & $\begin{array}{l}\text { Qaddhat et al., 2016; } \\
\text { Kovjanic, 2014; } \\
\text { El-Gohary, 2016 }\end{array}$ \\
\hline $\begin{array}{l}\text { 3. Gender } \\
\text { separation }\end{array}$ & $\begin{array}{l}\text { Widawati and Setiyorini, } \\
\text { 2014; (Rosenberg \& } \\
\text { Choufany, 2009) }\end{array}$ & 3. Adultery & Kovjanic, 2014 \\
\hline $\begin{array}{l}\text { 4. Shalat } \\
\text { service }\end{array}$ & $\begin{array}{l}\text { Widawati and Setiyorini, } \\
\text { 2014; Battour et al.,2010 }\end{array}$ & 4. Alcohol \& drugs & $\begin{array}{l}\text { Idris and Wahab, 2015; } \\
\text { Qaddhat et al., 2016 }\end{array}$ \\
\hline $\begin{array}{l}\text { 5. Paying } \\
\text { zakat }\end{array}$ & $\begin{array}{l}\text { El-Gohary, 2016; } \\
\text { Karim et al., 2017 }\end{array}$ & $\begin{array}{l}\text { 5. Sculpture and } \\
\text { images in the form } \\
\text { of living creatures }\end{array}$ & $\begin{array}{l}\text { Sahida, Rahman, } \\
\text { Awang, \& Man, 2011; } \\
\text { Karim et al., 2017 }\end{array}$ \\
\hline $\begin{array}{l}\text { 6. Halal food } \\
\text { guarantee }\end{array}$ & $\begin{array}{l}\text { Widawati and Setiyorini, } \\
\text { 2014; Battour et al., 2010; } \\
\text { Razalli et al., 2012 }\end{array}$ & 6. Usury or riba & $\begin{array}{l}\text { Karim et al., 2017; } \\
\text { Idris and Wahab, } 2015\end{array}$ \\
\hline
\end{tabular}

* All sources are generated from Al Qur'an and hadith of prophet of Muhammad

This is confirmed by the Standing Committee for Economic and Comercial Cooperation of the Organization of Islamic Cooperation (COMCEC) in 2016. They make classification of the formal standard of halal criteria into halal food and prayer facilities; a bathroom with clean and sufficient water; services and facilities in the fasting month, and; non-halal activities as well as recreational facilities and services. Thus, the two most important elements of the implementation of sharia principles which are halal food and shalat facilities have been completely fulfilled by the participants. Certification is necessary to guarantee the halal food because it is recommended by an official institution. It is an official recognition that a product is approved in Islamic law. This certificate will help consumers gain guarantee without any suspicion or doubt in consuming products and services (Eddahar, 2018), especially to ensure that food does not contain non-halal essence. It is also to make sure that the animals served are slaughtered with the Sharia law (Battour et al., 2010). Since shalat is a major obligation of Muslims, therefore the fulfillment of prayer facilities is in the top priority. Thus, they need clean and hygienic shalat room, sufficient water, shalat equipment and Al- Qur'an (Battour et al., 2010; Idris \& Wahab, 2015).

\section{Aspects of Service (Management)}

The implementation of management is clearly arranged in the Standard Operational Procedure (SOP). Preparation and supervision of the SOP is regularly discussed with the National Sharia Council - Indonesia Council of Ulama (MUI). The SOP is based on the principles of sharia in each of the category. The SOP is consistently implemented with high commitment. This is the synthesis of all interviews with respondents in halal operation. The management process shows products and services to users (Asnawi \& Fanani, 2017). In the end, the winners use halal principles in certain 
services consistently and firmly. Even though in Bali as non-Muslims population majority, if halal principles are consistently implemented, halal tourism will run successfully. In the beginning, it may be difficult to conduct halal business in Bali. On the contrary, if halal business is run in a predominantly Muslim region, the level of difficulty might be lower. The operators of halal tourism should be aware that halal has become the lifestyle of the world's consumers (Rahim et al., 2013). It is not only for Muslim consumers but also for non-Muslims. The non-Muslim consumers do not only demand halal products and services for the sake of religion, but it is also for health and security. In addition, Muslim tourists are more critical with the guarantee of halal as Muslim tourists have better awareness of the importance of halal tourism (Zulkifli et al., 2011). The implementation of a SOP due to work process must obey the certain halal requirements. The formulation of SOP should be standardized that it can be understood and implemented by all stakeholders. In short, SOP is not only for tourism operators but also for the tourists. In the context of tourism, standardization is an effort to improve facilities, procedures, and actions in a certain way to ensure the quality of services (Widayati \& Setiyorini, 2014).

\section{Aspects of Human Resource}

This study synthesized the character building and competence of tourism operators to provide halal-based services. It is based on the interviews with all participants in human resource management. They implement it by providing special training about the practice of halal service. It is also rebuilt through religious speech (tausyah) on halal products and services regularly. Even if the employees are not Muslim, they must follow SOPs in providing sharia-compliant business services such as hygiene, separation between halal (allowed) and haram (forbidden). Thus, it is highly obliged in Islamic ways. King and Grace (2005) state that employees contribute a lot to business organization and marketing chain. In Islam, marketing affairs should use a good, clear and consistent in model of human resource behavior. The aim is to create long-term customer satisfaction, loyalty and trust (Asnawi \& Fanani, 2017). Ideally, human resources in halal tourism should be dominated by Muslim employees (El-Gohary, 2016; Idris \& Wahab, 2015). This issue is related to the character of employees in religious tourism to keep specific-religious-related knowledge (Kartal et al., 2015). The goal is for the ease of service because Muslim employees already have basic understanding of what is allowed and not allowed in Islam. Nevertheless, in practice, some problems might appear in the process. For instance, it is happended in Bali as the majority of non-Muslim human resources. To deal with this problem, SOP and trainings are highly required in order to understand the fundamentals of services in the principles of Islamic, especially hygiene issues, halal materials and the separation of halal and haram.

\section{Aspects of Finance}

Based on the result of the research, some sharia tourism operators have already used sharia accounts for all transactions and business finance. Meanwhile, some others still do it partially and even some have not used sharia accounts yet. This condition is influenced by various internal and external situations encountered by the tourism operators in their business. The process in business cannot be separated from the financial aspects. It is not only about how the business is financed but it is also related to the cash flows through various transactions in the transaction of business. A sharia tourism business is based on the fatwa of DSN-MUI.108/DSN-MUI/X/2016 on Guidance on Implementing of Sharia-Compliant Tourism. It maintains the obligation to apply sharia financial institutions in providing services with the principles of Islam. The concepts of conventional transactions are generally against the Islamic rules. Some of the case studies are attentiveness practices (loaning or riba) and insecurity (gharar) (Asnawi \& Fanani, 2017). These things differentiate sharia from conventional practices. 
The awareness phenomenon to halal business is generated by the growth of Islamic population in the sharia finance industry. The rise of the Islamic financing institutions is also related to the growth of hotels and other sharia businesses, as some sharia financial and non financial institutions demand that businesses finance or management transactions must be in the principles of sharia (Razalli et al., 2012). In fact, the practices of shariacompliant tourism business are also fluctuating. Some operators do it totally, but some others do it partially by using both sharia and conventional accounts, or even some do not use the sharia at all. In the criteria of the interest of halal tourism business by (COMCEC, 2016), basically sharia financial system in the management of sharia tourism is explicitly stated. However, "nice to have" aspect could be a prohibition of non-halal business activities. It would certainly be better if this aspect could be implemented since it is essential of sharia-compliant business. The business funding shall be based on shariabased contracts and the owner is obliged to give contributions (Idris \& Wahab, 2015).

\section{Constraints and Alternative Solutions}

Since halal tourism is specific, some certain requirements shall be fulfilled in its implementation. In addition, several of the requirements may be constraints for tourism operators. The capability to manage constraints in business process is limited by the availability of organizational resources, such as financial, human resource, technology, etc (Paltayian et al., 2017). The synthesis of interviews from the participants reveals that there is a similar answer about improved cost and reduced potential revenues. They are the constraints to implement sharia principles in halal business process. Thus, all of halal tourism business operators have decided to implement a half of sharia business model in their process since it would be very costly. Transformation to halal tourism business process certainly must be managed cautiously. Many business process are fail, It causes overruns for the organization (Jurisch et al., 2016). In fact, this phenomenon takes place either in Indonesia or other countries. Some international hotel managements refuse the implementation of Islamic principles at their hotels because they do not want to lose potential profits from the sale of alcohol (Razalli et al., 2012) and the potential loss of guests (Henderson, 2010). Moreover, high cost capacity management is required to separate men and women to interact (ikhtilath) due to immediate relative relationship (Battour et al., 2010; Henderson, 2010; Razalli et al., 2012). That would be the reason of some halal tourism operators to remove the sharia principles totally in their business processes. They prefer to adopt a more compromising method of Muslim-friendly business patterns (El-Gohary, 2016). The implementation of the pattern can save the cost and satisfy the demand of Muslim tourists who are not strictly to Islam. Some of people are moderately practicing Islam, and few of them are even non-practicing Islam in their life other than just for doing mandatory orders such as shalat and not consuming haram food (COMCEC, 2016).

Cost is one of business structural attractiveness (Rahman, 2003) and it also could be dilemma for some business. High cost and loss of potential income are the biggest dilemma in halal tourism operators. Different approach can be the solution to solve these problems (Dalgic \& Leeuw, 1994). It treats the tourism market as niche-specific market. Halal tourism operators should prioritize the quality more than quantities such as achieving the certain target of the number of tourists. Although the quantity is small, but the niche-specific consumer groups have high purchasing power (Dalgic \& Leeuw, 1994). They are willing to pay at premium price as long as the services is good (Sert, 2017). Price is determined by the costs. Price for marketer is cost for consumers (Asnawi \& Fanani, 2017). It is a simple formula. It is natural that the cost of tourism in sharia practices is compensated at the end into different price. The price may be more expensive than conventional services because halal tourism operators are obliged to provide a number of 
requirements of halal-based tourism (Eddahar, 2018). Halal tourism operators should be aware that niche marketing practices enable them to impose more expensive price because they are required consumers needs (Toften \& Hammervoll, 2013).

It will be good condition for Muslim tourists who belong to segment A. They are a group of tourists who strictly practicing Islam. They are very obedient to their religious principles (COMCEC, 2016). The religious tourists are eager to pay at a premium price to manage the additional costs by operators due to the implementation of the concept of Islamic tourism business (Razalli et al., 2012). Some hotels can impose an expensive price to compensate losses for not selling liquor (Saad et al., 2014). The key is that the price shall be clearly informed to consumers. Halal tourism operators should consider the price. It is not too expensive and no fraud in the business because it is strictly prohibited in Islam (Asnawi \& Fanani, 2017). Clear and fair information is needed to elevate knowledge and awareness to the customer (Akbar et al., 2015). That is the main basic different of the concept of halal to the conventional ones. The differentiation takes consequences to the emergence of different price to conventional business process.

\section{CONCLUSIONS AND IMPLICATIONS}

Halal tourism has tremendous potentials to be developed due to Muslim consumer awareness of sharia even in tourism activities. Islam is not only set worshiping God but also directing the relationship between human beings (muamalah). The concept of halal tourism is a concept of tourism in certain needs. Both findings of interview and literature review reveal that there are extra costs in order to fulfill the needs to sharia-compliant tourism. The additional cost is a limitation for tourism business operators to change their business process from the conventional to the halal concept. Thus, it is a problematic issue to run a halal tourism business from the very beginning.

This research proposed solution to impose a premium pricing practice in halal tourism services. Psychological pricing practice is no longer based on functional and rational benefits which are commonly used in conventional marketing practices, but it is based on emotional and spiritual reasons instead. Therefore, promotion and education to foster awareness of maintaining the values of the sharia in tourism business are required. Customer's awareness is the best solution to inform customers about the different concept of halal tourism business and the conventional tourism business. Thus, the price of halal business products is more expensive. If it is consistent, halal business operators will be no longer worried about potential of loss. Business operators will not loss the customers. However, it will shift the customer segments from the conventional to specific customers as halal tourism products and services. If this is applicable, halal tourism operators will not be in a dilemma. It is now on the consumers' hand whether they still want to pay cheaply for tourism products and services. It has no halal guarantee or customers pay a bit more money to consume halal-guaranteed tourism product or services.

\section{LIMITATION AND FURTHER RESEARCH}

The perspectives of this study are mostly based on the best practices by the participants which are the world best halal operators. However, this research did not measure tourist's perspective about halal-related products, management, human resource and finance. Further study may be conducted to find out Muslim's satisfaction in halal-business.

\section{Acknowledgment}

Thanks to Directorate General of Strengthening Research and Development, Ministry of Research, Technology and Higher Education of the Republic of Indonesia in Institutional National Strategy of Research Grant (first of two year-stage-research) 2017 that has fully funded this research in 2017 and finished in 2018. 


\section{REFERENCES}

Akbar, F., Omar, A. R. Bin, \& Wadood, F. (2015). Niche Marketing Strategy and Firm Success: Review on SMEs in Peninsular Malaysia. International Journal of Research and Review, o2(11), 697-702.

Alim, H. T., Riansyah, A. O., Hidayah, K., Muslim, I., \& Adityawarman. (2015). Analysis of the Potential of Sharia Tourism by Optimizing Creative Industries in Central Java and Yogyakarta. Analisis Potensi Pariwisata Syariah Dengan Mengoptimalkan Industri Kreatif di Jawa Tengah dan Yogyakarta. Jurnal Akuntansi FEB Universitas Diponegoro, Semarang, 1-8.

Asnawi, N., \& Fanani, M. A. (2017). Sharia Marketing: Theory, Philosophy and Contemporary Issues. Pemasaran Syariah: Teori, Filosofi, dan Isu-Isu Kontemporer. Depok: Raja Grafindo Persada.

Battour, M. M., Ismail, M. N., \& Battor, M. (2010). Toward a Halal Tourism Market. Tourism Analysis, 5, 1-10. https://doi.org/10.3727/108354210X12864727453304

Boediman, E. P. (2017). Halal Lifestyle in Marketing Communication of Tourism and Hospitality. International Journal of Economic Research, 14(14), 429-438.

Bohari, A. M., Hin, C. W., \& Fuad, N. (2013). The Competitiveness of Halal Food Industry in Malaysia: A SWOTICT Analysis. Geografia; Malaysia Journal of Society and Space, 9(1), 1-9.

Chadwick, R. A. (1987). Concepts, Definitions, and Measures Used in Travel and Tourism Research. In J. R. B. Ritchie \& C. . Goeldner (Eds.), Travel, Tourism, and Hospitality Research: A Handbook for Managers and Researchers (pp. 52-53). New York: John Wiley \& Sons, Inc.

Creswell, J. W. (2014). Research Design: Qualitative, Quantitative \& Mixed Methods Approaches, 4th ed. Sage Publication, London.

Dalgic, T., \& Leeuw, M. (1994). Niche Marketing Revisited: Concept, Applications and Some European Cases. European Journal of Marketing, 28(4), 39-55. https://doi.org/10.1108/03090569410061178

Dogan, M. (2011). Turkiye Deislamiturizmingelisimi 2002-2009. In Political Economy, Crises and Development (pp. 471-487). Istanbul.

Eddahar, N. (2018). Muslim Friendly Tourism Branding In The Global Market. Research Report of Islamic Center for the Development of Trade by Organization of Islamic Cooperation. Retrived from https://www.oic-oci.org/docdown/?docID=1772\&refID $=1071$.

El-Gohary, H. (2016). Halal tourism, is it really Halal? Tourism Management Perspectives, 19, 124-130. https://doi.org/10.1016/j.tmp.2015.12.013

Firdaus, F. (2018). Potency of Integrated Cultural Tourism Development at Maninjau Lake Area, West Sumatera. Mimbar: Jurnal Sosial Dan Pembangunan, 34(1), 72-82.

Firdaus, F., Shalihin, N., Anggreta, D. K., Yasin, F., \& Tutri, R. (2019). Improving The Benefits of Karamba Into Tourism Activities: An Effort To Reduce The Ecological Impact Of Aquaculture In Maninjau Lake, Indonesia. GeoJournal of Tourism and Geosites, 26(3), 726-736. https://doi.org/10.30892/gtg.26304-392

Goeldner, C. R., \& Ritchie, J. R. B. (2009). Tourism: Principles, Practices, Philosophies, $11^{\text {th }}$ edition. NJ: John Wiley \& Sons, Inc.

Graf, L., \& Ossig, C. (2002). Review of the Concept of Travel Typologies : The Case of Switzerland. Tourism Review, 57(4), 28-32.

Harahsheh, F. (2019). The effect of cultural dimensions on tourism promotion in Jordan. Management Science Letters, 9, 43-52. https://doi.org/10.5267/j.msl.2018.11.001

Henderson, J. C. (2010). Sharia-Compliant Hotel. Tourism and Hospitality Research, 10(3), $246-254$. https://doi.org/10.1057/thr.2010.3

Idris, J., \& Wahab, N. A. (2015). The Competitive Advantages Of Sharia-Compliant Hotel Concept In Malaysia : SWOT Analysis. In Proceeding of the 2nd International Conference on Management and Muamalah 2015 (2nd ICoMM) (pp. 200-209).

Jaelani, A. (2017). Halal Tourism Industry in Indonesia: Potential and Prospects. International Review of Management and Marketing, $7(3), 25-34$.

Jurisch, M. C., Rosenberg, Z., \& Krcmar, H. (2016). Emergent Risks in Business Process Change Projects. Business Process Management, 22(4), 791-811. https://doi.org/10.1108/BPMJ-01-2015-0002

Karim, M. H. A., Ahmad, R., \& Zainol, N. A. (2017). Differences in Hotel Attributes : Islamic Hotel And Sharia Compliant Hotel in Malaysia. Journal of Global Business and Social Entrepreneurship, 1(2), 157-169.

Kartal, B., Tepeci, M., \& Atl, H. (2015). Examining the religious tourism potential of Manisa , Turkey with a marketing perspective. Tourism Review, 7O(3), 214-231. https://doi.org/10.1108/TR-09-2013-0048

King, C., \& Grace, D. (2005). Exploring the role of employees in the delivery of the brand: a case study approach. Qualitative Market Research: An International Journal, 8(3), 277-295. https://doi.org/10.1108/13522750510603343

Kovjanic, G. (2014). Islamic Tourism as a Factor of the Middle East Regional Development. Turizam, 18(1), $33-43$.

Leiper, N. (1979). The Framework Of Tourism. Annals Of Tourism Research, o6(4), 390-407.

Ma, J., \& Law, R. (2009). Components of Tourism Research : Evidence from Annals of Tourism Research. Anatolia: An International Journal of Tourism and Hospitality Research, 2O(1), 62-74.

Musa, G., Ali, S. B. M., \& Moghavvemi, S. (2016). Understanding Islamic (Halal) Tourism Through Leiperrs Tourism System. https://doi.org/10.2139/ssrn.2813023 
Osman, F., Hussin, S., Yusof, R. N. R., Hashim, H., Abd.Aziz, Y., \& Nezakati, H. (2015). Special Needs of Muslim Family Tourists Across The Family Life Cycle: Stakeholders' Perspectives. Australian Journal of Basic and Applied Sciences, 9(3), 108-112.

Paltayian, G., Gotzamani, K. D., Georgiou, A. C., \& Andronikidis, A. (2017). Aligning customer requirements and organizational constraints to service processes and strategies. Business Process Management Journal, 23(5), 1018-1042. https://doi.org/10.1108/BPMJ-10-2015-0140

Qaddhat, R., Attaalla, F., \& Hussein, M. M. (2016). Halal Tourism: Evaluating Opportunities and Challenges in the Middle East "Jordan and Egypt." Journal of Faculty of Tourism and Hotels, Fayoum University, 10(2), 377-390.

Rahim, N. F., Shafii, Z., \& Shahwan, S. (2013). Awareness and Perception of Muslim Consumers on Non-Food Halal Product. In Proceedings of 4th International Conference on Education and Information Management (ICEIM-2013) (pp. 192-201).

Rahman, S. H. (2003). Modelling of International Market Selection Process : A Qualitative Study of Successful Australian International Businesses. Qualitative Market Research: An International Journal, 6(2), 119-132. https://doi.org/10.1108/13522750310470127

Razalli, M. R., Abdullah, S., \& Hassan, M. G. (2012). Developing a Model for Islamic Hotels: Evaluating Opportunities and Challenges. In International Proceeding of Economic Development and Research, No. 42 Jeju Island, South Korea (pp. 91-95).

Rinschede, G. (1992). Forms Of Religious Tourism. Annals Of Tourism Research, 19(1), 51-67. https://doi.org/ 10.1016/0160-7383(92)90106-Y

Rosenberg, P., \& Choufany, H. M. (2009). Spiritual Lodging -the Sharia-Compliant Hotel Concept. Retrieved from http://www.4hoteliers.com/4hots_fshw.php?mwi=4010.

Saad, H. E., Ali, B. N., \& Abdel-Ati, A. M. (2014). Sharia-Compliant Hotels In Egypt: Concept and Challenges. Advances in Hospitality and Tourism Research (AHTR), 2(1), 1-15.

Sahida, W., Rahman, A. R., Awang, K., \& Man, Y. B. C. (2011). The Implementation of Shariah Compliance Concept Hotel: De Palma Hotel Ampang, Malaysia. In 2011 2nd International Conference on Humanities, Historical and Social Sciences (Vol. 17, pp. 138-142).

Samori, Z., Ishak, A. H., \& Kassan, N. H. (2014). Understanding the Development of Halal Food Standard: Suggestion for Future Research. International Journal of Social Science and Humanity, 4(6), 482-486. https://doi.org/10.7763/IJSSH.2014.V4.403

Sekaran, U., \& Bougie, R. (2013). Research Methods for Business: A Skill-Building Approach, 6th ed. West Sussex: John Wiley \& Sons, Inc.

Sert, A. N. (2017). Niche Marketing And Tourism. Journal of Business Management and Economic Research, 1(1), 14-25. https://doi.org/10.29226/jobmer.2017.1

Sigaux, J. (1996). History of Tourism. London: Leisure Arts.

Stergiou, D. P., \& Airey, D. (2018). Understandings of tourism theory. Tourism Review. https://doi.org/ 10.1108/TR-07-2017-0120

Sugiyono. (2015). Management Research Methods. Metode Penelitian Manajemen. Bandung: Alvabeta.

Toften, K., \& Hammervoll, T. (2013). Niche marketing research : status and challenges. Marketing Intelligence \& Planning, 31(3), 272-285. https://doi.org/10.1108/02634501311324618

Vukonic, B. (1996). Tourism and Religion. Pergamon, Oxford.

Wall, G., \& Mathieson, A. (2006). Tourism: Change Impact and Opportunities. Pearson Prentice Hall, Essex.

Widayati, R., \& Setiyorini, H. . (2014). Sociolinguistic Perspective: Dialogue between Islam and Non Islam on Islamic Tourism Standarization. Jurnal Manajemen Resort \& Leisure, 11(2).

Wyllie, R. W. (2011). An Introduction To Tourism. Venture Publishing, Inc.

Yuswohady. (2015). Marketing to the Middle Class Muslim. Jakarta: Gramedia Pustaka Utama.

Zamani-Farahani, H., \& Musa, G. (2012). The relationship between Islamic religiosity and residents' perceptions of socio-cultural impacts of tourism in Iran: Case studies of Sare'in and Masooleh. Tourism Management Journal, 33, 802-814. https://doi.org/10.1016/j.tourman.2011.09.003

Zulkifli, W. S. W., Rahman, S. A., Awang, K. W., \& Man, Y. B. C. (2011). Developing The Framework for Halal Friedly Tourism in Malaysia. International Business Management, 5(6), 295-302. https://doi.org/ 10.3923/ibm.2011.295.302

*** COMCEC. (2016). Muslim Friendly Tourism: Understanding the Demand and Supply Sides In the OIC Member Countries.

*** DSN-MUI. Guidelines for Organizing Tourism Based on Sharia Principles. Pedoman Penyelenggaraan Pariwisata Berdasarkan Prinsip Syariah, Pub. L. No. 108/DSN-MUI/X/2016 (2016). Indonesia.

Submitted:

20.08.2019
Revised:

02.12.2019
Accepted and published online 05.12.2019 